AUTORES (p.o. de firma): V. Andreu, A. Imeson y J.L. Rubio.

TITULO: "Temporal changes in soil macro and microaggregation induced by forest fire and its incidence on water erosion”.

Revista: CATENA

Volumen: 44

Páginas, inicial: 69

final: $84 \quad$ Fecha: 2001 


\title{
Temporal changes in soil aggregates and water erosion after a wildfire in a Mediterranean pine forest
}

\author{
${ }^{\mathrm{a}}$ V. Andreu, ${ }^{\mathrm{b}}$ A.C. Imeson \& ${ }^{\mathrm{a}}$ J.L. Rubio. \\ ${ }^{a}$ Centro de Investigaciones sobre Desertificación-CIDE (CSIC, Universidad de Valencia, Generalitat \\ Valenciana). Camí de la Marjal, s/n, 46470-Albal, Valencia, Spain. \\ ${ }^{b}$ Fysisch Geografisch en Bodemkundig Laboratorium, Landscape and Environmental Research Group. \\ Universiteit van Amsterdam. Nieuwe Prinsengracht, 130. 1018VZ Amsterdam, The Netherlands.
}

\begin{abstract}
The evolution of soil structure after a forest fire was studied on two zones representatives of a typical Mediterranean Pine forest. These zones were in opposite slope orientation but with similar topographical and pedological characteristics. Changes in soil macro-aggregation and water stable micro-aggregation were monitored seasonally during a year after the fire. The water erosion patterns were also studied from August 1993, immediately after the fire, to the end of 1996.

The first five centimeters of soil depth were the most affected by fire temperature, showing clear differences on aggregate distribution and temporal variability between zones. In the north facing soil a substantial and gradual recovery on soil aggregation was observed mainly in the fraction greater than $5 \mathrm{~mm}$ diameter, this reached an increase of $27 \%$ in mass of aggregates. In the south slope the evolution of aggregation was smooth and restricted to
\end{abstract}

Correspondence should be addressed to V. Andreu at the above address.

Fax: (34)96 1270967

E-MAIL: vicente.andreu-perez@uv.es 
the fraction minor than $0.1 \mathrm{~mm}$. These differences between zones are reflected also in their values on soil cohesiveness and compaction, being lesser in the south oriented soils. Values of erosion parameters show that both zones have the higher soil losses during the immediate period (four months) after the fire, being more important in the south zone. This zone produced more sediment and runoff (52.42\% and $29.95 \%$, respectively) than north facing soils for the whole period studied.

Keywords: Soil aggregation, soil properties, water erosion, forest fire, burned soils, Mediterranean forest.

\section{Introduction}

Fire is one of the major ecological factors that has shaped the Mediterranean landscape and influences its present mosaic-like pattern. Forest fires act in soils by means of its thermal impact, affecting soil in different ways depending on its intensity (temperature, residence time, etc.). These effects are translated in changes on chemical and physical soil properties. In general, water repellence and aggregate stability are the most important soil physical parameters that can be altered by fire (Giovannini et al., 1987; Diaz-Fierros et al., 1990; Josá et al., 1994). They would influence soil porosity and hydrology favoring runoff production and the incidence of water erosion processes.

Aggregate stability depends on the internal cohesiveness between constituent clay particles. This cohesiveness is mediated by binding agents such as humic substances, which form strong complexes with Fe, $\mathrm{Al}$ and $\mathrm{Mg}$ (Nwadialo and Mbagwu, 1991). These binding agents are deeply affected by fire temperature and, in connection with with clays, promoting important changes in soil structure. Other components, like calcium carbonates, 
could influence aggregation at high temperatures. In this sense micro-aggregation plays an important role in crusting, surface sealing, soil permeability, water infiltration and seedling emergence (Miller and Baharuddin, 1986). Micro-aggregation is affected by fire being involved in the structural soil changes. The degradation of soil microstructure could produce a decrease in porosity and infiltration, reducing cohesiveness of soil particles and favouring runoff production and soil removal by water erosion (Giovaninni, 1994; Reichert and Darrell, 1994).

This study analyses the temporal evolution on soil aggregates, induced by the effect of fire on two burned zones representative of a typical Mediterranean pinewood forest. These zones have different slope position in the same catchment. The effect of these differences on runoff production and soil loss by water erosion has also been studied since immediately after the wildfire (August 1993) until the end of 1996.

\section{Material and methods}

\subsection{Study area}

In August 1993 a wildfire took place in Sierra Calderona, a mountainous area located in the Mediterranean coast of Spain near Valencia. The different speeds and directions of propagation, together with the complex topography of the area produced irregular and complex patterns of fire impacts. The burned area of Sierra Calderona has an extension of 9498 ha (Figure 1). Of the whole zone, 6007 ha were of typical Mediterranean pinewood forest and, occasionally, cork oaks and the rest was characterised by shrubland and some agricultural plots.

In this study, two sampling zones within the burnt area were selected. The soils studied were of similar characteristics, and affected by fires of similar intensities (Table 1). All of them are calcareous soils of Rendzinic Leptosol/Haplic Calcisol type association (FAO- 
UNESCO, 1988), developed on Triasic (Muschelkalk) materials. They show variable depth (35-100 cm) with a high stone content (25\%), and a sandy loam texture. Their chemical and physical characteristics are reported in Tables 2 and 3 respectively. The soils studied were the following:

A.- Soil that suffered a high intensity fire (temperature higher than $400^{\circ} \mathrm{C}$ ), north slope oriented.

B.- Soil of similar lithology and characteristics as Soil A, that also suffered a high intensity fire, but in south orientation.

The degree of fire intensity was established by the method of Moreno and Oechel (1989) based on correlating estimate of fire intensity with the minimum branch diameters that remains after the fire and the colour of ashes.

All the studied soils are located in hillsides with slopes that vary between $30 \%$ and 35\%. Their vegetation cover corresponds to a typical Mediterranean Pine forest with shrubs of the Rosmarino-ericion association, characterized mainly by $\underline{\text { Rosmarinus }}$ officinalis, Erica $\underline{\text { multiflora, }}$ Asparagus horridus, Ulex parviflorus, and Globularia alipum.

\subsection{Sampling}

Forty samples of the first ten centimetres depth of each sampling zone were randomly taken and stored in plastic boxes to avoid perturbations as possible. The first set of samples was taken immediately after the fire. Unfortunately, the extent of the wildfire in the whole area did not allow to obtain a sampling zone unburned to be used as control, then we take as starting point the soil just burned.

In the laboratory, the samples were air dried and passed through a column of sieves of different diameters (5mm, $2 \mathrm{~mm}, 0.85 \mathrm{~mm}, 0.42 \mathrm{~mm}, 0.3 \mathrm{~mm}, 0.1 \mathrm{~mm})$ until separation of 
the fraction minor to $0.1 \mathrm{~mm}$. Gravels were separated and quantified in each sample by fractions of more than $5 \mathrm{~mm}$ and from 2 to $5 \mathrm{~mm}$.

Simultaneously, twenty samples of the sediment removed by runoff and accumulated in the catchment, closer to the studied zones, were also taken and treated in the same way than the soil samples.

From each global sample twenty subsamples were taken for analysis. The sampling was repeated seasonally to cover one year period.

To monitor the erosion patterns in the studied zones, ten control stations were established, five in each sampling zone. In these stations sediment and runoff collector systems were set up to evaluate the soil erosion processes (Figure 2). Intensive field surveys were carried out to select areas with a natural pattern of a close microcatchment and with a point of downslope flows concentration. This configuration avoids the disturbance derived from the construction of artificial boundaries. The average size of the microcatchments correspondent to the stations on the north faced zone was $24.61 \mathrm{~m}^{2}$, and for those in the south faced zone was $25.59 \mathrm{~m}^{2}$. The equipment of the stations includes a pluviometer and a system of runoff and sediment collection based in a modification of the Gerlach trap (Rubio et al., 1997).

Twenty-four rain events with runoff production were registered from September 1993 until November 1996. The sediments and runoff collected in each trap were quantified.

\subsection{Apparatus and analysis}

The evolution in the content of water stable microaggregates, as aggregates with diameter lower than $250 \mu \mathrm{m}$ (Tisdall and Oades, 1982; Beare et al., 1994), was performed employing an analyser of particles by $\mathrm{X}$ ray beams, in two runs (Cammeraat and Imeson, 1998). The apparatus was a MICROSCAN II of Quantachrome ${ }^{\mathrm{TM}}$, with ultrasounds 
module. In a first step, the sample of soil sieved at diameter lower than $0.105 \mathrm{~mm}$ was passed through the analyser, in a distilled water solution. In the second step a dispersion treatment was applied to obtain a second size distribution of primary particles. Dispersion of the sample was carried out by treatment with $1 \mathrm{ml}$ of $\mathrm{Na}_{4} \mathrm{P}_{2} \mathrm{O}_{7} 0.12 \mathrm{M}$ and later application of ultrasounds at energy level of $1800 \mathrm{~J}$ during one minute. The difference between the particle size distributions, resulting from each step, was used as an indicator of the water stable microaggregates existing in the soil sample.

Organic matter content was determined by oxidation with potassium dichromate (Jackson, 1958) and cation exchange capacity by extraction with $1 \mathrm{M}$ ammonium acetate solution at $\mathrm{pH}=7$ (Rhoades, 1982). Total and mineral nitrogen were determined by a Kjeltec Auto 1030 Analyser using the Bremmer method (Black, 1965), and total carbonate content using the Bernard calcimeter method (Duchaufour, 1965). Electrical conductivity was measured in soil saturation extracts by the method of Richards (1964). Available phosphorous was measured by colorimetry according to the method of Olsen \& Dean (Black, 1965). Aggregate stability was assessed using a wet-sieving procedure (PrimoYufera and Carrasco, 1973). Soil cohesiveness was measured with a torvane and compaction, in the first $5 \mathrm{~cm}$ depth, was measured with a Stiboka penetrograph (Eijkelkamp 6.02). The core method (McIntire, 1974) was used to measure soil bulk density.

Standard statistical analyses, ANOVAs and Tukey’s multiple range test $(\alpha=0.05)$ were applied to determine statistical differences between soils North and South faced.

\section{Results and discussion}

Results obtained show relevant differences between the studied soils, mainly on the evolution of aggregation and in the impact of water erosion. Statistically significant 
differences $(\mathrm{P}=0.05)$ on chemical parameters (Table 2), between north and south oriented soils, were observed. The values of aggregate stability and organic matter are higher in the north faced soil while mineral nitrogen increases in the south faced one. Marqués \& Mora (1992) reported similar results on soils of burned Mediterranean pine forests. The existing vegetation cover, before the fire, more dense in the north slope, and the higher irradiation that suffer the south faced soils increased evapo-transpiration and favoured mineralisation of organic matter. All these circumstances and the high calcium carbonate content of these soils, mainly in the south orientation, could influence the evolution of aggregation and hydrological characteristics (Ekwue, 1991; Imeson et al., 1992).

The study of aggregation reflects that the zone most affected by heat, in both soils, was the surface first $50 \mathrm{~mm}$, mainly in the fraction of aggregates with diameter $>5 \mathrm{~mm}$ (Figures 3 and 4). Soils north oriented show an increase in this fraction of $27 \%$ in the first $50 \mathrm{~mm}$ (Figure 3). Fraction of $\varnothing 2-5 \mathrm{~mm}$ shows a similar trend at the same soil depth. Fraction of $\varnothing 1-2 \mathrm{~mm}$ reflects similar course, but decreases with time in the zone of 5-10 cm depth. The aggregation progressively increases in these soils in all the aggregate fractions, but only the fraction minor than $\varnothing 0.1 \mathrm{~mm}$ shows a great increment with time in the whole $10 \mathrm{~cm}$ depth.

Soils south oriented show the greatest structural degradation by fire. Significant differences between slopes, especially in aggregates greater than $\varnothing 5 \mathrm{~mm}$ (Figures 3 and 4), could be observed. In this case the difference reach a maximum in the zone of 0.5 to $5 \mathrm{~cm}$ depth, in which the $\%$ in weight of aggregates $>\varnothing 5 \mathrm{~mm}$ in the north slope was $\cong 30 \%$ higher than in the other slope. The only fraction that increase in south slope compared to the north zone is that minor than $\varnothing 0.5 \mathrm{~mm}$, mainly in the fraction $<\varnothing 0.1 \mathrm{~mm}$, which suggests a degradative effect on soil structure. This agrees with the observations of Panayiotopoulos \& Kostopoulou (1989) studying the aggregate stability dependence on different factors of red Mediterranean soils (Alfisols). However, a slight recovery of the 
structure with time in this zone could be also observed, although less pronounced than in north faced soils.

In relation to water stable micro-aggregation (Figure 5), soil A shows an increase in winter with a progressive recovery starting from the end of summer. This variation is focused on the fractions from 16 to $32 \mu \mathrm{m}$. Meanwhile in the south oriented soil (B) no clear recovery was observed, with a minor percentage of aggregates that was distributed in the fractions lower than $\varnothing 16 \mu \mathrm{m}$. Then the structural degradation becomes more evident and progressive. These observations are according to those of Blackman (1992) about the effect of "seasonality" in soils of the UK South Downs.

After the fire, the predominant fraction in the studied sediments (Figure 6) corresponds to $\varnothing 0.5-1 \mathrm{~mm}$, until winter, which it could be due to the hammering effect of rainfall and the decrease of the biological activity (Hillel, 1980; Lynch, 1984). After winter, variations in the aggregate size distribution were not observed, with the exception of the fraction minor to $\varnothing 0.3 \mathrm{~mm}$ that augmented slightly. In all cases, the fraction of aggregates larger than $\varnothing 2 \mathrm{~mm}$ was minimal. Respect to water stable microaggregates, peaks were shown in the rain season (autumn) increasing the fraction from $\varnothing 4$ to $105 \mu \mathrm{m}$ (Figure 6).

The micro-aggregation increases progressively giving the highest percentage of aggregates in the range of $\varnothing 16-105 \mu \mathrm{m}$. Generally, it could be assumed that the evolution of aggregation in these soils is according to the biological activity, decreasing in summer and recovering slightly after the autumn rains.

As a whole, the temporal variations are clearer in the macroaggregates than in microaggregates (Blackman, 1992; Molina, 1993), showing an increase in winter and later spring and a clear decrease in summer.

The stage of soil aggregation could affect other physical parameters, which is observed in the increase of bulk density and soil compaction (Table 3), with a decrease of 
cohesiveness in the soil B (Table 3). Significant differences have been observed on these parameters between soils north and south faced, and they show the same trend with respect to the erosion parameters.

To establish the effect of water erosion on this soils, twenty-four erosive rainfall events -with runoff production- were studied (Figure 7), since the end of the fire in September 1993 till the end of 1996. In each of them, runoff produced and soil losses were quantified (Table 4). Significant differences have been observed on both parameters between soils with north and south aspect (Figure 8). Total sediment production in soil A, north oriented, was 52.42\% lower than soil B. It means a sediment yield 50.54\% minor in soil A respect to the values of soil $\mathrm{B}$.

Total values on runoff generated are $29.95 \%$ lower in soil A than in B, which corresponds to a $27.10 \%$ decrease in runoff yield in soil A respect to the values of B. These values are slightly higher than those reported by Marqués and Mora (1992) studying the effect of slope position on Mediterranean soils that suffered medium-low intensity wildfires. Zohar et al. (1990) and Kutiel and Inbar (1993), working on burned mature Pine forest plantations of Israel, obtain similar values on erosion parameters than those observed in the north faced soil.

However, a common fact has been observed for both soils, the highest soil losses were produced in the four months immediately after the fire (Figure 8).

Soil/stones ratio is a parameter that could be useful as indicator of soil erosion effects. It is the ratio between the percentage in dry weight of the net soil divided by the percentage in weight of stones with diameter higher than $2 \mathrm{~mm}$, referred both to the total weight of the complete sample taken in the first $5 \mathrm{~cm}$ depth. This ratio scarcely decreases with time on both soils but is more accentuated in the south oriented (Figure 9), which shows always the lowest values. It is strongly related with the results of soil losses by water erosion in both 
soils. In the same way, a strong decrease of this ratio could be observed in the sediments with time. This observation shows that the greatest soil losses were produced in the first rains after the fire, and it is according to the evolution of the erosion parameters, mainly with sediment production.

\section{Conclusions}

Differences have been observed between Mediterranean burned soils in opposite slope orientations on chemical and physical properties, which affects the incidence of water erosion processes. Soil organic matter and structural stability show lower levels in south facing soils; meanwhile ammonium nitrogen and calcium carbonate content increases.

Fires of high intensity affect the aggregation of the first $50 \mathrm{~mm}$ of soil surface. This effect is mainly focused on the fraction of aggregates with diameters higher than $2 \mathrm{~mm}$. The degradative effect of heating is also observed in the increase of aggregates with diameters lower than $0.1 \mathrm{~mm}$. This fraction is always greater in the south oriented soils.

Seasonal evolution is clearer on macroaggregates than in microaggregates. After the fire, an increase in aggregation is observed in winter and later spring to decrease strongly in summer and with the autumn rains characteristics of the Mediterranean climate.

The fraction of microaggregates of 16-32 $\mu \mathrm{m}$ reflects better these variations, showing a recovery at the end of winter in the north facing soil, but there is no clear recovery of the micro-structure in the south facing soils. In them, the increasing proportion of microaggregates of less than $\varnothing 16 \mu \mathrm{m}$ reflects a progressive degradation.

In the sediments of the catchment the predominant fraction of aggregates ranges from $\varnothing 0.5-1 \mathrm{~mm}$. Aggregates with diameter major than $2 \mathrm{~mm}$ are minimum. After winter equilibrium in the aggregate size is observed, only the fractions lower than $\varnothing 0.3 \mathrm{~mm}$ increases slightly. 
The effect of the aggregation state of these soils affects their physical properties, showing significant differences $(\mathrm{P}=0.05)$ on soil bulk density, cohesiveness and compaction.

Significant differences have been also observed on erosion parameters, where north facing soils produce less runoff and soil losses, in $29.95 \%$ and $52.42 \%$ respectively, than soils south oriented. A common trend for both soils is that the highest values of soil losses are produced in the four months immediately after the fire.

Soil/stones ratio gives an indication of the impact of erosion on soils. The evolution of its values agrees with the development of the erosion processes on the studied soils.

\section{References}

Beare, M.H., Cabrera, M.L., Hendrix, P.F., Coleman, D.C., 1994. Aggregate-protected and unprotected organic matter pools in conventional- and no-tillage soils. Soil Sci. Soc. Am. J., 58: 787-795.

Black, C.A., 1965. Relaciones suelo-planta. Ed. Hemisferio Sur, Buenos Aires.

Blackman, J.D., 1992. Seasonal variation in the aggregate stability of downland soils. Soil Use Manage., 8: 142-150.

Cameraat, L.H., Imeson, A.C., 1998. Deriving indicators of soil degradation from soil aggregation studies SE Spain and S France. Geomorphology, 23: 307-321.

Diaz-Fierros, F., Benito, E., Vega, J.A., Castelao, A., Soto, B., Pérez, R., Taboada, T., 1990. Solute loss and soil erosion in burnt soil from Galicia (NW Spain). In: J.G. Goldammer and M.J. Jenkins (Editors), Fire in ecosystem dynamics. SPB Academic Publishing, The Hague, pp. 103-116.

Duchaufour, P., 1965. Precís de Pedologie. Masson et Cie., Paris. 
Ekwue, E.I., 1991. The effects of soil organic matter content, rainfall duration and aggregate size on soil detachment. Soil Tech., 4: 197-207.

FAO-UNESCO, 1988. Soil map of the World 1:5.000.000. Revised legend. FAO, Rome.

Giovannini, G., 1994. The effect of fire on soil quality. In: M. Sala, and J.L. Rubio (Editors), Soil erosion as a consequence of forest fires. Geoforma Ediciones, Logroño, pp. 15-29.

Giovannini, G., Luchesi, S., Giachetti, M., 1987. The natural evolution of a burned soil: a three year investigation. Soil Sci., 143: 220-226.

Hillel, D., 1980. Fundaments of soil physics. Academic Press Inc., London.

Imeson, A.C., Verstraten, J.M., van Mulligen, E.J., Sevink, J., 1992. The effects of fire and water repellency on infiltration and runoff under Mediterranean type forest. Catena, 19: 345-361.

Jackson, M.L., 1958. Soil chemical analysis. Prentice Hall Inc., London.

Josá, R., Arias, X., Solé, A., 1994. Effects of slashburning on some physical properties in an olm-oak coppice. In: M. Sala, and J.L. Rubio (Editors), Soil erosion as a consequence of forest fires. Geoforma Ediciones, Logroño, pp. 29-42.

Kutiel, P., Inbar, M., 1993. Fire impacts on soil nutrients and soil erosion in a Mediterranean pine forest plantation. Catena, 20: 129-139.

Lynch, J.M., 1984. Interactions between biological processes, cultivation and soil structure. Plant and Soil, 76: 307-318.

Marqués, M.A., Mora, E., 1992. The influence of aspect on runoff and soil loss in a mediterranean burnt forest (Spain). Catena, 19: 333-344. 
McIntyre, D.S., 1974. Soil sampling techniques for physical measurements. Chapter 3: Bulk density. In: J. Loveday, (Editor), Methods of analysis of irrigated soils Farnham Royal, Bucks, pp. 174-208.

Miller, W.P., Baharuddin, M.K., 1986. Relationship of soil dispersibility to infiltration and erosion of southeastern soils. Soil Sci., 142: 235-240.

Molina, M.J., 1993. Changes in soil aggregate water stability induced by wetting-drying cycles in heated soils. In: L. Trabaud and R. Prodon (Editors), Fire in Mediterranean ecosystems. Commission of the European Communities, Brussels. pp. 413-422.

Moreno, J.M., Oechel, W.C., 1989. A simple method for estimating fire intensity after a burn in California chaparral. Acta Æcologica, 10(1): 57-68.

Nwadialo, B.E.,Mbagwu, J.S.C., 1991. An analysis of soil components active in microaggregate stability. Soil Tech., 4: 343-350.

Panayiotopoulos, K.P, Kostopoulou, S., 1989. Aggregate stability dependence on size cultivation and various soil constituents in red Mediterranean soils (Alfisols). Soil Tech., 2: 79-89.

Primo-Yufera, E., Carrasco, J.M., 1973. Química Agrícola. I. Suelos y fertilizantes. Alhambra, Madrid.

Richards, L.A., 1964. Diagnosis and improvement of saline and alkali soils. Agriculture Handbook 6, USDA, Washington,D.C.

Reichert, J.M., Darrell, L., 1994. Aggregate stability and rain-impacted sheet erosion of air-dried and prewetted clayey surface soils under intense rain. Soil Sci., 158(3): 159-169. 
Rubio, J.L., Forteza, J., Andreu, V., Cerni, R., 1997. Soil profile characteristics influencing runoff and soil erosion after forest fire: A case study (Valencia, Spain). Soil Tech., 11: 67-78.

Tisdall, J.M., Oades, J.M., 1982. Organic matter and water stable aggregates in soils. J. Soil Sci., 33:141-161.

Zohar, Y., Weinstein, A., Frankel, H., Kutiel, P., Israeli, A., 1990. Prescribed burning as a tool in forest management. J.N.F. Forest Service Technical Report-17, Tel Aviv. 


\section{Table 1}

Characteristics and fire parameters of the studied soils

\begin{tabular}{|c|c|c|}
\hline & \multicolumn{2}{|c|}{ Soils } \\
\hline & A & B \\
\hline Lithology & Limestones and Dolomies & Limestones and Dolomies \\
\hline Soil Classification & $\begin{array}{l}\text { Haplic Calcisol/Rendzic } \\
\text { Leptosol }\end{array}$ & $\begin{array}{l}\text { Haplic Calcisol/Lithic/Rendzic } \\
\text { Leptosols }\end{array}$ \\
\hline Soil Depth (cm) & 80 & $50-80$ \\
\hline Slope (\%) & 30 & 35 \\
\hline Orientation & Northeast & South \\
\hline Altitude (m) & 580 & 600 \\
\hline Vegetation & Pine, coscojar & Pine, coscojar \\
\hline Fire Intensity & High & High \\
\hline Fire Type & $\begin{array}{l}\text { Total. Stumps and roots. } \\
\text { Rubefaction. }\end{array}$ & All levels. Stump fire \\
\hline
\end{tabular}




\section{Table 2}

Mean values of some chemical characteristics of the studied soils

\begin{tabular}{|c|c|c|}
\hline & $\mathbf{A}^{\mathbf{a}}$ & $\mathbf{B}^{\mathbf{b}}$ \\
\hline Water content (weight \%) & $4.2 \pm 0.6 \mathrm{a}^{\mathrm{c}}$ & $3.1 \pm 0.9 \mathrm{a}$ \\
\hline Aggregate stability (\%) & $42.9 \pm 2.2 \mathrm{a}$ & $32.0 \pm 4.2 b$ \\
\hline $\mathrm{pH}$ & $7.6 \pm 0.0 \mathrm{a}$ & $7.6 \pm 0.0 \mathrm{a}$ \\
\hline Electrical Conductivity $\left(\mathrm{dS} \mathrm{m}^{-1}\right)$ & $1.08 \pm 0.1 \mathrm{a}$ & $1.00 \pm 0.1 \mathrm{a}$ \\
\hline Carbonate content ( weight \%) & $28.1 \pm 3.0 \mathrm{a}$ & $49.8 \pm 5.3 b$ \\
\hline Organic Matter ( weight \%) & $10.8 \pm 0.3 a$ & $6.8 \pm 0.2 b$ \\
\hline Total N (\%) & $0.7 \pm 0.1 \mathrm{a}$ & $0.6 \pm 0.3 a$ \\
\hline Mineral N $\left(\mathrm{g} \mathrm{kg}^{-1}\right)$ & $5.70 \pm 0.1 \mathrm{a}$ & $7.22 \pm 0.0 \mathrm{~b}$ \\
\hline Available P $\left(\mathrm{g} \mathrm{kg}^{-1}\right)$ & $0.62 \pm 0.2 \mathrm{a}$ & $1.30 \pm 0.5 b$ \\
\hline Cation Exchange Capacity $\left(\mathrm{cmol}_{\mathrm{c}} \mathrm{kg}^{-1}\right)$ & $36.00 \pm 7.5 a$ & $26.45 \pm 9.0 \mathrm{a}$ \\
\hline $\mathrm{Ca}\left(\mathrm{mol}_{\mathrm{c}} \mathrm{kg}^{-1}\right)$ & $31.57 \pm 3.4 \mathrm{a}$ & $20.06 \pm 5.1 b$ \\
\hline $\operatorname{Mg}\left(\operatorname{mol}_{\mathrm{c}} \mathrm{kg}^{-1}\right)$ & $2.54 \pm 1.1 \mathrm{a}$ & $5.20 \pm 2.0 \mathrm{a}$ \\
\hline $\mathrm{Na}\left(\mathrm{mol}_{\mathrm{C}} \mathrm{kg}^{-1}\right)$ & $0.14 \pm 0.0 \mathrm{a}$ & $0.29 \pm 0.1 \mathrm{a}$ \\
\hline $\mathrm{K}\left(\mathrm{mol}_{\mathrm{c}} \mathrm{kg}^{-1}\right)$ & $1.67 \pm 0.5 a$ & $0.90 \pm 0.3 a$ \\
\hline
\end{tabular}

${ }^{a}$ Burned soil North oriented. ${ }^{b}$ Burned soil South oriented. ${ }^{c}$ Values followed by the some letter in the row are not significantly different $(\mathrm{P}<0.05)$ using Tukey’s multiple range test. 
Table 3

Mean values of some physical characteristics of the different soils studied

\begin{tabular}{lcc}
\hline Particle Size (\%) & $\mathrm{A}^{\mathrm{a}}$ & $\mathrm{B}^{\mathrm{b}}$ \\
\hline$<0.002 \mathrm{~mm}$ & $7.5 \mathrm{a}^{\mathrm{c}}$ & $14.5 \mathrm{~b}$ \\
$0.002-0.005 \mathrm{~mm}$ & $5.0 \mathrm{a}$ & $5.0 \mathrm{a}$ \\
$0.005-0.02 \mathrm{~mm}$ & $10.7 \mathrm{a}$ & $11.7 \mathrm{a}$ \\
$0.02-0.05 \mathrm{~mm}$ & $11.5 \mathrm{a}$ & $10.7 \mathrm{a}$ \\
$0.05-0.10 \mathrm{~mm}$ & $9.2 \mathrm{a}$ & $10.2 \mathrm{a}$ \\
$0.10-0.25 \mathrm{~mm}$ & $15 \mathrm{a}$ & $14.9 \mathrm{a}$ \\
$0.25-0.50 \mathrm{~mm}$ & $20.3 \mathrm{a}$ & $13.8 \mathrm{~b}$ \\
$0.50-1.0 \mathrm{~mm}$ & $13.3 \mathrm{a}$ & $8.6 \mathrm{~b}$ \\
$1.0-2.0 \mathrm{~mm}$ & $6.5 \mathrm{a}$ & $9.4 \mathrm{a}$ \\
Classification & Sandy loam & Sandy loam \\
Stoniness $(\%)$ & $31.2 \pm 8.4 \mathrm{a}$ & $42.4 \pm 7.7 \mathrm{a}$ \\
Bulk density $\left(\mathrm{g} \mathrm{cm}^{-3}\right)$ & $1.04 \pm 0.01 \mathrm{a}$ & $1.49 \pm 0.05 \mathrm{~b}$ \\
Compaction $\left(\mathrm{N} \mathrm{cm}^{-2}\right)^{\mathrm{d}}$ & $70 \pm 11.70 \mathrm{a}$ & $130 \pm 15.23 \mathrm{~b}$ \\
Cohesivity $\left(\mathrm{k} \mathrm{cm}^{-2}\right)$ & $3.89 \pm 0.47 \mathrm{a}$ & $2.38 \pm 0.34 \mathrm{~b}$ \\
\hline
\end{tabular}

${ }^{a}$ Burned soil North oriented. ${ }^{b}$ Burned soil South oriented ${ }^{c}$ Values followed by the some letter in the row are not significantly different $(\mathrm{P}<0.05)$ using Tukey’s multiple range test. ${ }^{\mathrm{d}}$ Measure referred to the first $5 \mathrm{~cm}$ of soil depth. 


\section{Table 4}

Values of some erosion parameters in the studied soils for the period September 1993-November 1996.

\begin{tabular}{|c|c|c|c|}
\hline & & $\mathrm{A}^{\mathrm{a}}$ & $\mathrm{B}^{\mathrm{b}}$ \\
\hline \multirow{3}{*}{ Runoff (l) } & Total & 68.09 & 97.20 \\
\hline & Mean & $2.84 a^{c}$ & $4.05 b$ \\
\hline & Maximum & 28.10 & 40.55 \\
\hline \multirow{3}{*}{ Runoff yield (l m²) } & Total & 2.77 & 3.80 \\
\hline & Mean & $0.11 \mathrm{a}$ & $0.16 a$ \\
\hline & Maximum & 1.14 & 1.58 \\
\hline \multirow{3}{*}{ Runoff Coefficient (\%) } & Total & 6.02 & 5.98 \\
\hline & Mean & $0.29 a$ & $0.24 \mathrm{a}$ \\
\hline & Maximum & 0.94 & 1.24 \\
\hline \multirow{3}{*}{ Sediment (g) } & Total & 578.93 & 1216.73 \\
\hline & Mean & $25.17 \mathrm{a}$ & $50.70 \mathrm{~b}$ \\
\hline & Maximum & 137.20 & 295.78 \\
\hline \multirow{3}{*}{ Sediment yield $\left(\mathrm{g} \mathrm{m}^{-2}\right.$ ) } & Total & 23.52 & 47.55 \\
\hline & Mean & $1.02 \mathrm{a}$ & $1.99 b$ \\
\hline & Maximum & 5.57 & 11.56 \\
\hline \multirow{3}{*}{ Sediment discharge $\left(\mathrm{g} \mathrm{l}^{-1}\right)$} & Total & 744.19 & 1384.19 \\
\hline & Mean & 31.03a & $57.67 b$ \\
\hline & Maximum & 471.44 & 712.74 \\
\hline \multirow{3}{*}{ Erosion threshold } & Rain (mm) & 11.6 & 6.8 \\
\hline & Runoff yield ( $\left(\mathrm{m}^{-2}\right)$ & 0.11 & 0.04 \\
\hline & Sediment yield $\left(\mathrm{g} \mathrm{m}^{-2}\right)$ & 0.20 & 1.00 \\
\hline
\end{tabular}

${ }^{a}$ Burned soil North oriented. ${ }^{b}$ Burned soil South oriented. All the values are referred to the means of the correspondent group of stations. ${ }^{\mathrm{C}}$ Values followed by the some letter in the row are not significantly different $(\mathrm{P}<0.05)$ using Tukey's multiple range test. 


\section{FIGURE CAPTIONS}

Fig. 1: Location of the studied area.

Fig. 2: General configuration of the stations.

Fig. 3. Evolution of macroaggregates in first $10 \mathrm{~cm}(0-0.5 \mathrm{~cm}, 0.5-5 \mathrm{~cm}, 5-10 \mathrm{~cm}$ depth) of the North faced burned soils. (9) Winter 1993. ( $\square$ ) Spring 1994. ( $\square$ ) Summer 1994. (+) Autumn 1994.

Fig. 4. Evolution of macroaggregates in first $10 \mathrm{~cm}(0-0.5 \mathrm{~cm}, 0.5-5 \mathrm{~cm}, 5-10 \mathrm{~cm}$ depth of the South faced burned soils. (9) Winter 1993. ( $\square$ ) Spring 1994. ( $\square$ ) Summer 1994). (+) Autumn 1994.

Fig.5. Seasonal evolution of water stable microaggregates in the studied soils. (A) Burned soil North faced. (B) Burned soil South faced.

Fig. 6. Seasonal evolution of water stable microaggregates (A) and macroaggregates (B) in the sediments of the catchment.

Fig. 7. Amount of rain (mm) of each erosive rainfall event occurred from August 1993 to the end of 1996 in the studied zones.

Fig. 8. Runoff and sediment produced in each erosive rain event during the studied period in the North faced (grey) and South faced (white) soil. 
Fig. 9. Temporal evolution of the soil/stones ratio (\%) referred to the first $5 \mathrm{~cm}$ depth of the studied soils, and in the sediment of the catchment. (White) North faced. (Black) South faced. (Grey) Sediment. 
Figure 1

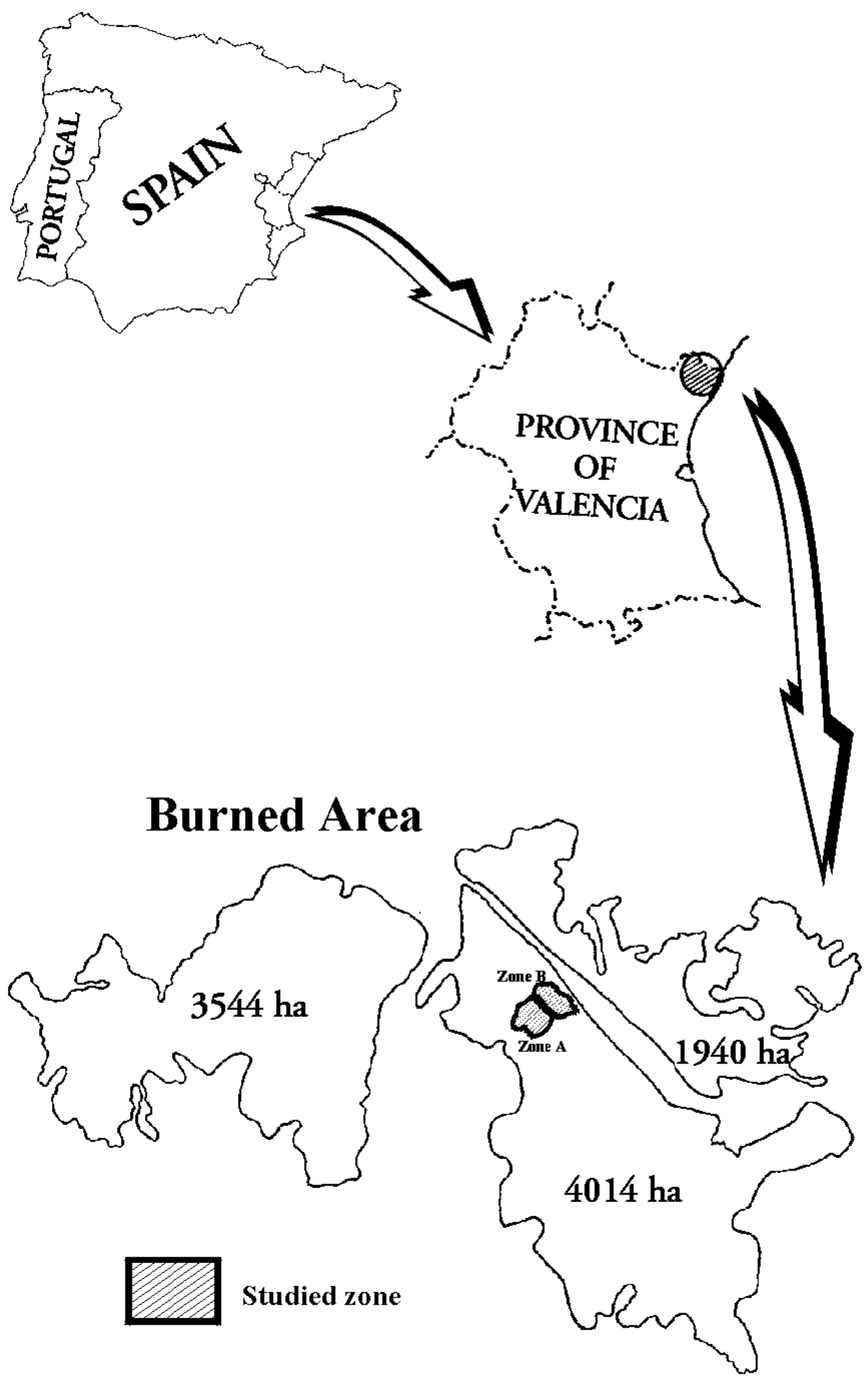


Figure 2

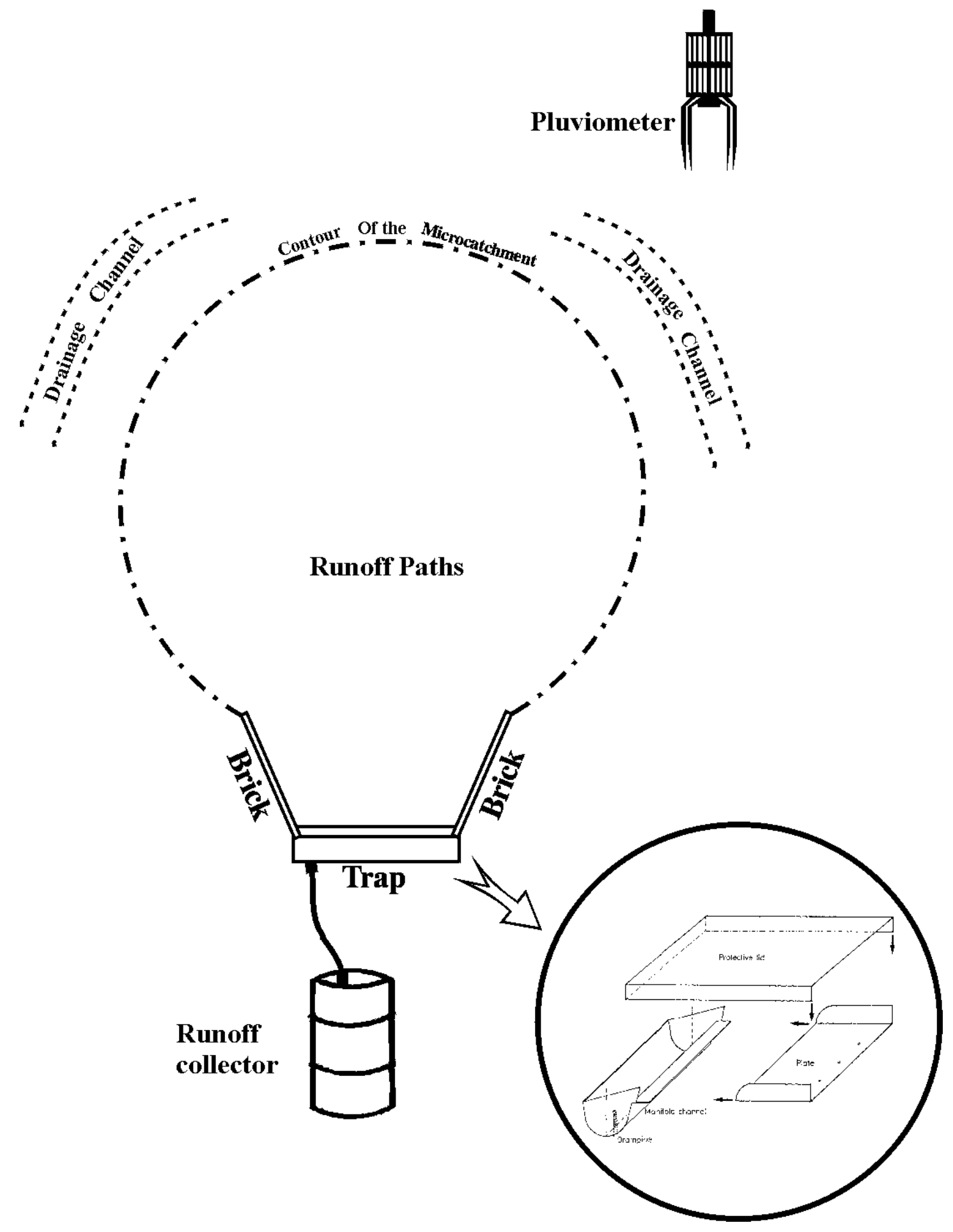


Figure 3

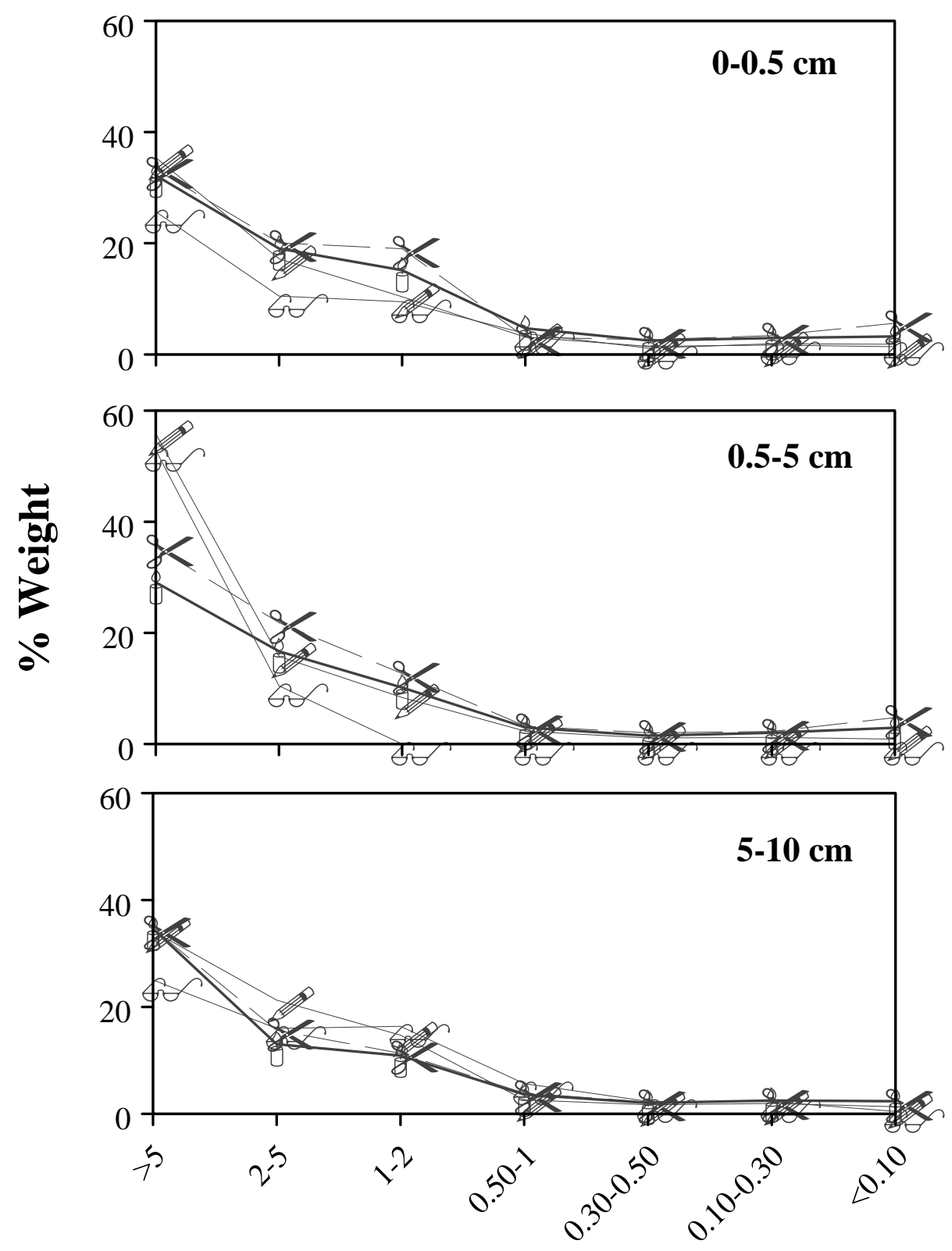

Aggregate Diameter (mm) 
Figure 4
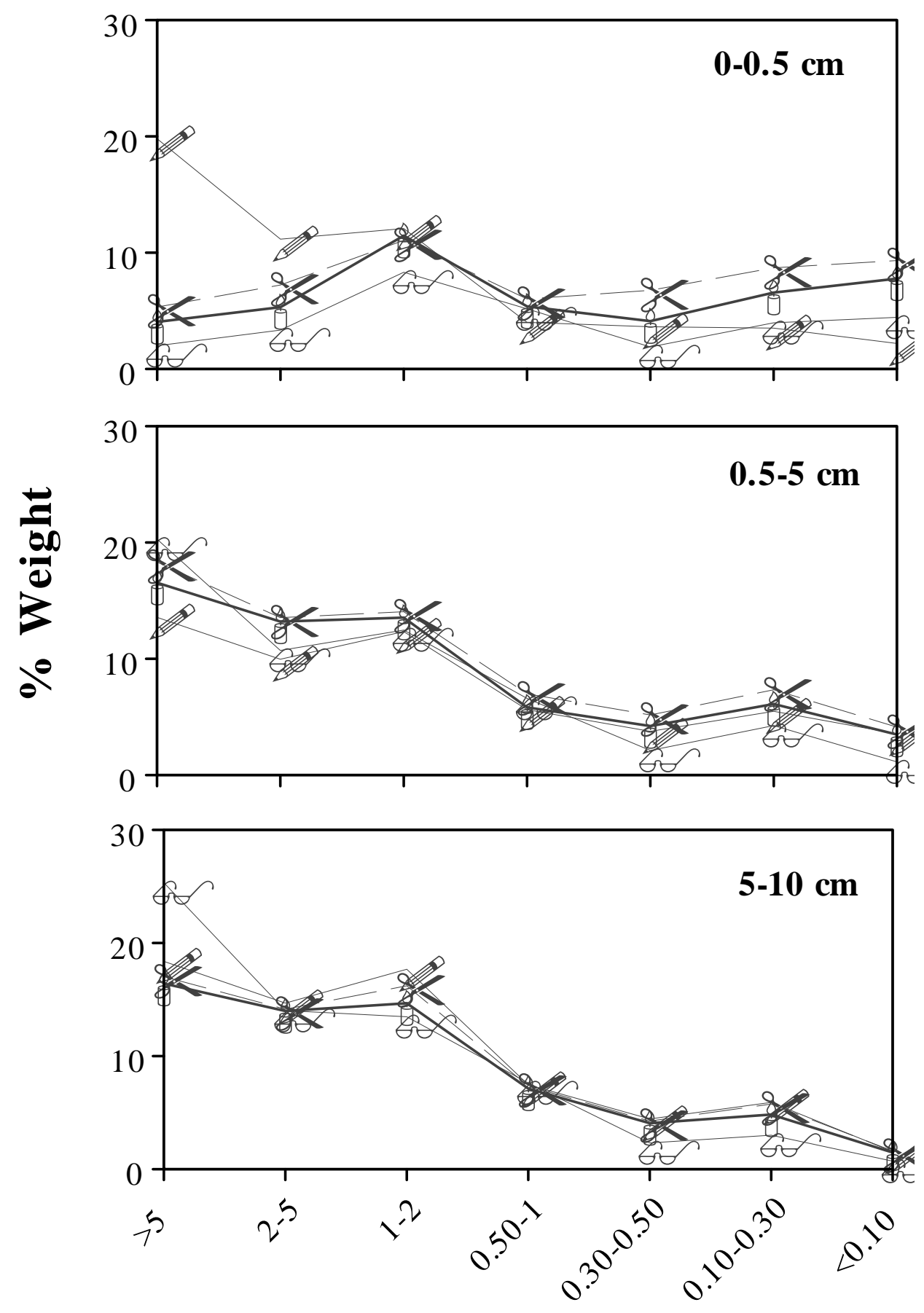

Aggregate Diameter (mm) 
Figure 5
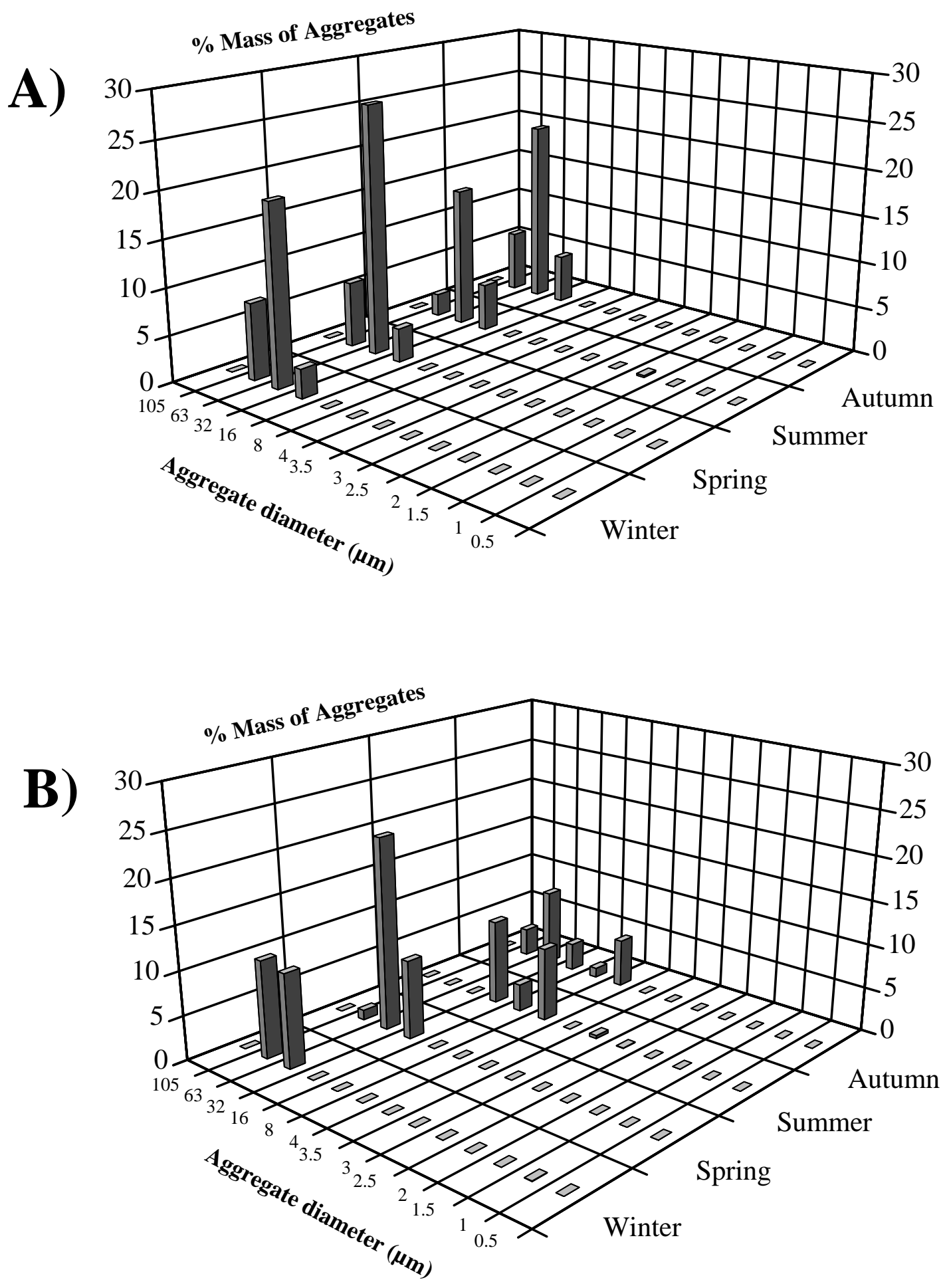
Figure 6
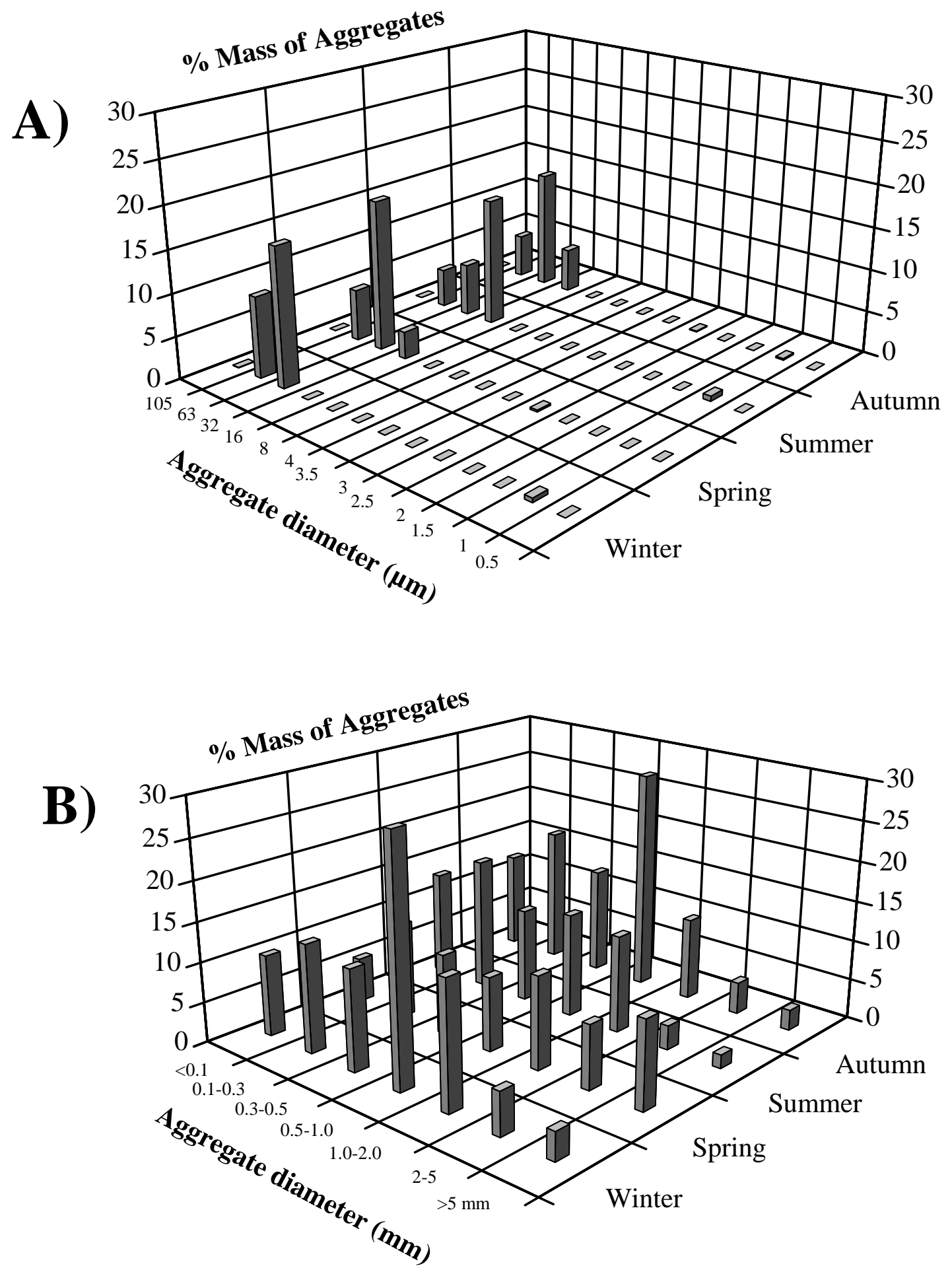
Figure 7

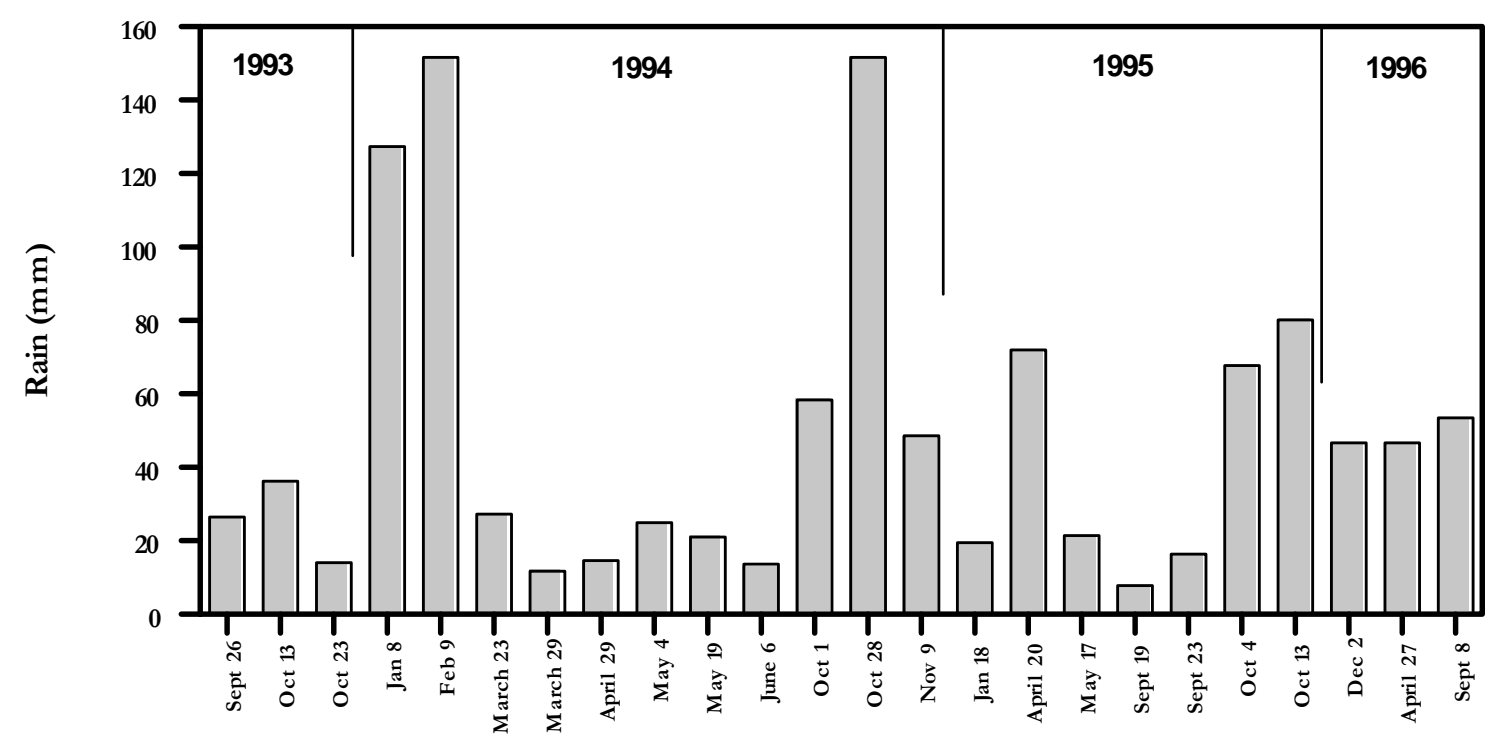

Rain Events 
Figure 8
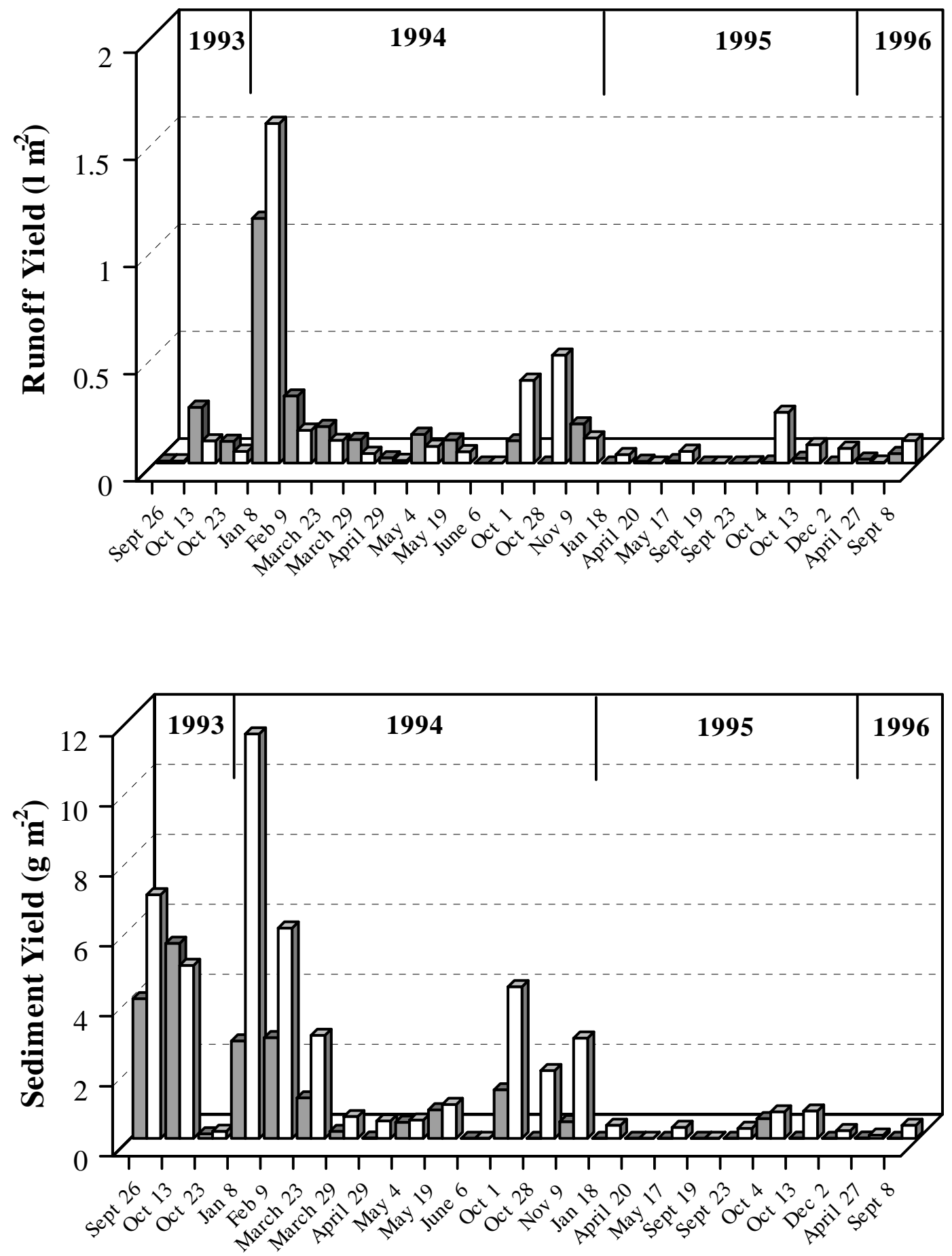

Rain Events 


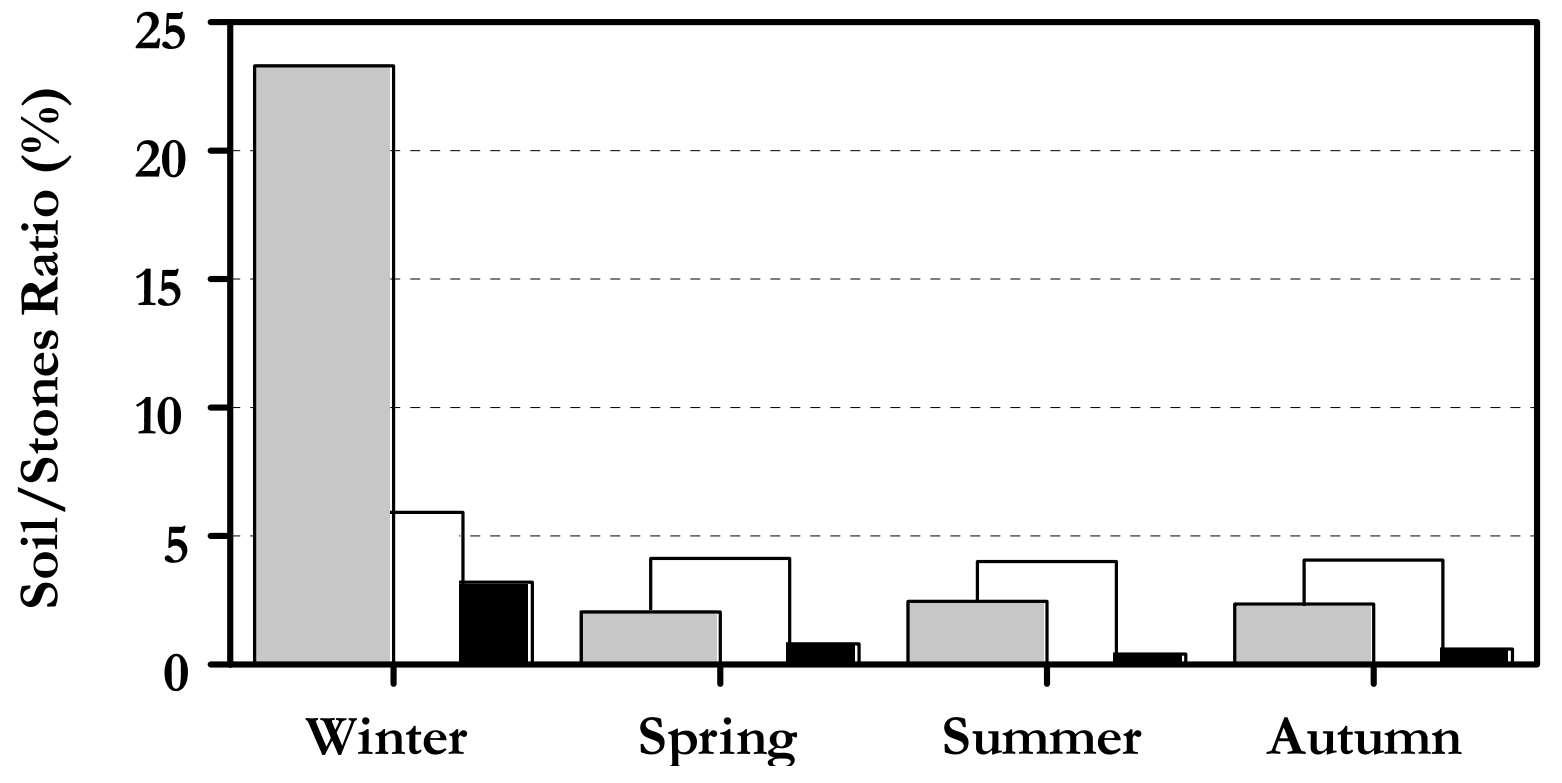

